Linguagem em (Dis)curso - LemD, v. 8, n. 2, p. 203-228, maio/ago. 2008

\title{
BEYOND THE PLAYGROUND: THE REPRESENTATION OF REALITY IN FASHION DOLLS' ADVERTISEMENTS
}

Danielle Barbosa Lins de Almeida*

\begin{abstract}
This article analyses the meanings conveyed by the discourse of web advertisements of the Brazilian fashion doll Susi, extracted from www.estrela.com.br. Drawing on Halliday's (1994) Systemic Functional Grammar for the analysis of the transitivity features and nominal groups, it focuses on the topics that Susi's ads reflect, the roles they convey and the type of relationship established among its participants. The analyses of the transitivity features of Susi's virtual advertisements have pointed to the construction of a world textually characterized by activities typical of the upper-middle class, which revolve around material and relational processes. The analysis of the nominal groups further specify the nature of such activities by relating them to affairs such as fashion, beauty, diet, sports, leisure, studies and career, altering, therefore, a traditional view on women's representation centered on the domestic sphere.
\end{abstract}

Keywords: discourse; gender; systemic functional grammar; advertisement; toy.

\section{INTRODUCTION}

Historically constructed to function as 'children's playthings', toys do not only constitute "replicas of the real world" but they also reveal "what 'goes on' in society, its ideology and values" (CALDASCOULTHARD; VAN-LEEUWEN, 2002, p. 94).

The meanings conveyed by toys are linked to social practices insofar as the social and cultural values that toys embed are largely

\footnotetext{
* Professor at the Universidade Federal da Paraíba (UFPB). PhD in English (with a focus on Applied Linguistics).E-mail:<danielle.almeida@gmail.com>.
} 


\section{4}

transmitted to children from early age and reproduced later on. Thus, toys constrain the way the child sees the world and, by doing so, they are assigned a fundamental role as cultural assets responsible for the construction of social identities.

Taking advantage of the fact that very little research has been devoted to the "supposedly trivial, feminine and frivolous world of dolls" (PEERS, 2004, p. 118) and its connection with the public domain, the research presented here aims at contributing to such an academic gap by proposing to investigate the structures of signification that lay behind the discourse of advertisements of the Brazilian doll Susi, retrieved from her website: www.estrela.com.br.

The trajectory of the discussion presented in this article will be guided by the following research questions:

(1) What meanings are encoded by the advertisements?

(2) What are their prevailing transitivity features?

(3) What lexical sets predominate in the advertisements, what do they reflect and what roles do they convey?

(4) What type of relationship is established among the participants involved in the advertisements?

In doing so, I expect to contribute to academic research by situating a linguistic analysis of contemporary media texts such as toy advertisements within the debates of broader interrelated fields such as consumerism, beauty, fashion, sexuality, childhood, ethnicity, social and gender roles.

\section{THE BRAZILIAN DOLL SUSI}

Susi fashion doll has been produced by Brazilian toy manufacturer Estrela since 1968, although its production was interrupted during the 1980's when Estrela got the license to produce Mattel's Barbie in Brazil. "Susi and Barbie are not rivals, though", says one of Estrela's employees (personal communication, 12th October 2004). "Barbie personifies a grown-up, successful and sexually-appealing woman whereas Susi stands 
for any typical middle or upper-class adolescent", she contends. Proof of this, so she says, is the fact that, in contrast to Barbie's body - who has got big breasts and a surrealistic tiny waist - Susis physical attributes evoke an average girl in her teens, "with her trim waist, small chest, wide thighs, and darker skin" (DOWNIE, 2000). "This is why there is no point in comparing both dolls", concluded the member of Estrela's staff.

Be that as it may, some of Susi and Barbie's visual representations do bear strong similarities: they entail adult activities such as being placed in domestic contexts which evoke marital life (Figure 1), household duties like being located in a 'super kitchen' or in a living room, going to the florist's or to the hairdresser's.
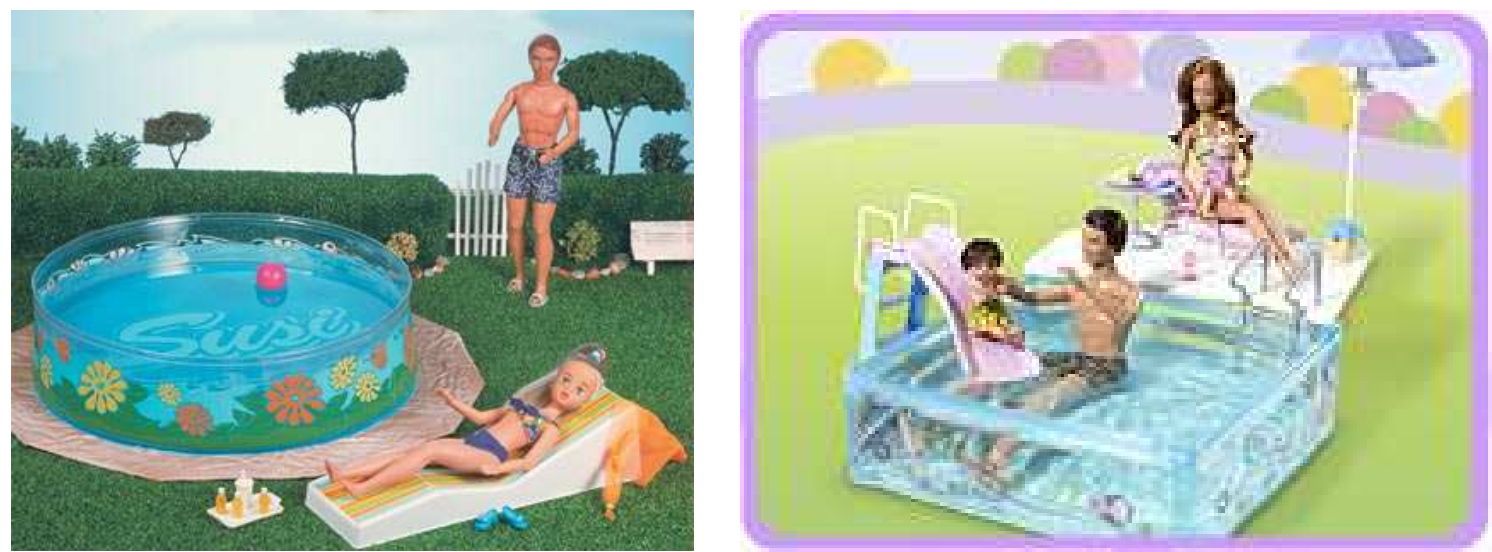

Figure 1 - Images of Susi and Barbie with their counterparts Beto and Ken, respectively, placed in adult contexts (retrieved from www.estrela.com.br and www.barbie.com).

Susis image also displays contradictory cultural values. Despite her pseudo validation of 'Brazilianness' (DOWNIE, 2000), Susi's physical representation evokes, in fact, the prototype of a typical American girl with her large blue eyes and straight, long, blonde hair, whereas Barbie can be mistakenly taken as a brunette Brazilian fashion doll whenever she is visually portrayed in one of her summer outfit versions (Figure2). 

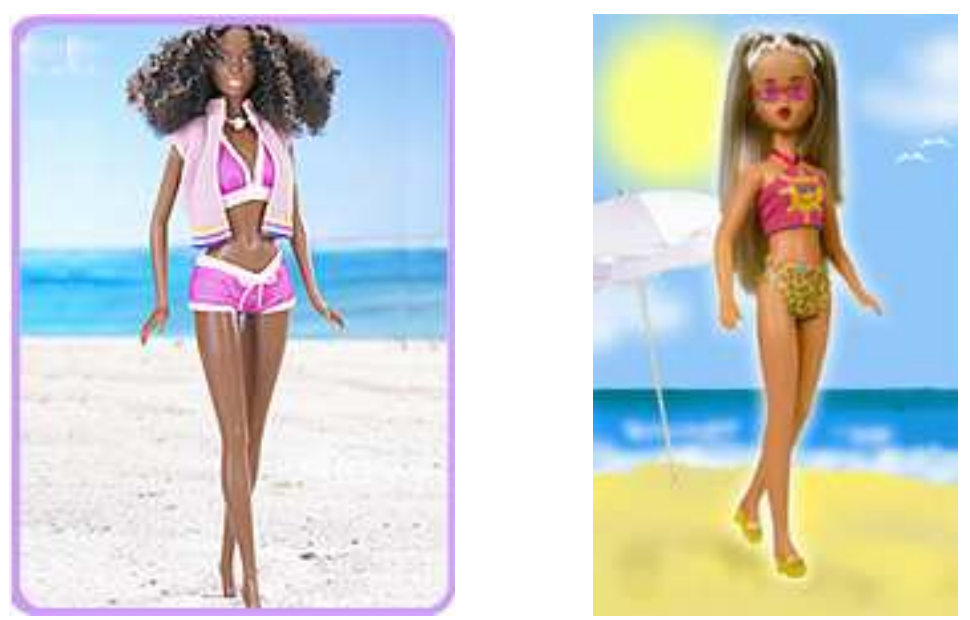

Figure 2 - Paradoxical relations between the images of Barbie and Susi in their summer outfit versions: 'Brazilianness' in Barbie and 'Americanness' in Susi? (retrieved from www.barbie.com and www.estrela.com.br).

In fact, Downie (2000) admits that, at first glance, Susi and Barbie are not that different as "both have impossibly long hair and clear blue eyes". Yet he also agrees with Estrela's marketing director Aries (quoted in DOWNIE, 2000) that Susis prototype has been moulded to look more Latin and therefore, more 'voluptuous'. Indeed, Aries (quoted in DOWNIE, 2000) fiercely defends that "Susi resonates with Brazilian girls" for a number of reasons:

$[\ldots]$ she has a body like them and all the themes and clothes are very Brazilian;

[...] Susis face is more circular than Barbie's and her mouth is rounder. Her eyelashes are longer and her skin is slightly darker $[\ldots]$;

Although the two dolls both have waistlines measuring four inches, the willowy Barbie has defied time to maintain her legendary hourglass figure and slim hips;

Susi $[\ldots]$ has a more modest bust and a pair of thighs measuring a whopping half-inch more than her American rival;

[Differently from Mattel's Barbie, who provides a role model for girls to aspire to], Susi shows them as they are, not as they want to be, $[\ldots]$ [as she] sees life through the eyes of a carefree young girl more interested in parties ('festas'). (DOWNIE, 2000) 
Contradictorily, the label 'Susi' itself does not seem to capture the arguable 'genuine' Brazilian essence of the doll. Instead, more appropriate label choices would be 'Susana', 'Ana' or 'Maria', all of which would somehow convey more authentic expressions of the Brazilian culture.

Another issue about Susi that deserves some reflection upon is her ethnicity. Although black Susi was launched in 1974, it is still blonde Susi who rules the roost.

Prior to the analysis of the actual advertisements retrieved from Susis website, I shall now present an overview of Halliday's (1994) Systemic Functional Grammar, which has been used as an analytical tool for the investigation of the transitivity structures and the nominal groups identified in Susis advertisements.

\section{SYSTEMIC FUNCTIONAL LINGUISTICS (SFL): TOOL FOR A LEXICO-GRAMMATICAL ANALYSIS}

The study of language under a Systemic Functional Linguistics (SFL) perspective has been used to explain lexicogrammatical choices in a way one is able to view language use as embedded in its social contextual environment. By utilising both social and contextual clues to deconstruct texts, Halliday's (1994) Systemic Functional Grammar offers a ground-breaking means of text analysis and interpretation in a range of different contexts.

Compared to its counterpart, the traditional or formal grammar, a 'functional' view on language, as the name itself suggests, goes beyond a set of prescriptive rules to classify the parts of speech to propose at a conceptualization of texts as entities embedded in two distinct contexts, namely the context of culture - the context in which it is possible to shape meanings in order to achieve specific goals in a particular culture and the context of situation - a context within the context of culture in which it is possible to determine the choices that users make either consciously or subconsciously by means of three discursive parameters called Field, Tenor and Mode. These variables are realised by what 


\section{8}

Halliday (1994) has referred to as 'metafunctions', namely, the ideational, interpersonal and textual metafunction.

The ideational metafunction involves looking for the processes in a text - linked to the notion of verbs, in traditional grammar -, constituted by events or relationships among things. In Hallidayan terms, the ideational metafunction is encoded by transitivity structures, whereby language is used to convey the user's picture of reality, his/her experience of the world. Within the ideational component of language, the system of transitivity is used to construe experience in terms of three functional constituents: Participant, Process and Circumstance. The participant constituent can be assigned one of the following roles: Actor, Agent, Goal, Carrier, or Sayer. The process constituent can also be divided into six basic types: material, mental and relational, considered as the major ones and described in terms of their subcategories - and behavioural, verbal and existential.

Table 1 summarises the six types of processes of the ideational metafunction.

\begin{tabular}{|l|l|l|}
\hline Process type & Subcategory & Participants involved \\
\hline Material & $\begin{array}{l}\text { event (i.e. happening) } \\
\text { action (i.e. doing) } \\
\text { perception } \\
\text { cognition } \\
\text { affection }\end{array}$ & Actor/goal \\
Relational & $\begin{array}{l}\text { attributive } \\
\text { identifying }\end{array}$ & Senser/phenomenon \\
Verbal & Carrier/attribute \\
Behavioural & & Sayer/Receiver \\
Existential & & \\
\hline
\end{tabular}

Table 1 - Types of processes. 
By recognising that ideational meanings are conveyed by transitivity structures that express the user's conception of reality (HALLIDAY, 1994) through his/her choice of Process, Participant(s) and Circumstance, it thus becomes natural to infer that the realization of meaning in a systemic functional perspective occurs within the clause dimension. In this respect, its grammar is structured around the clause, since its formal constituents can provide access to both syntactic and semantic features of language (HALLIDAY, 1994). The way this is realised in the clause is through verbal, nominal and prepositional groups, layers below the clause level which relate to Process, Participant and Circumstance, respectively. These relations can be better visualized through Figure 3.

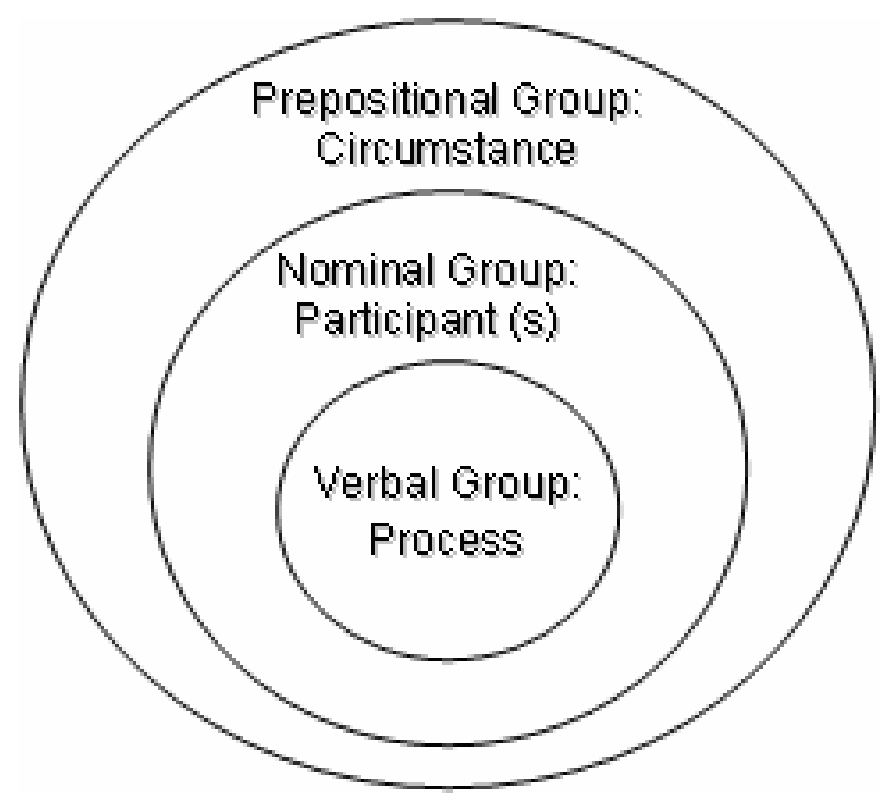

Figure 3 - Representation of reality within and below the clause level (extracted and adapted from BUTT et al, 1998, p. 42).

Prototypically, the Participant is realised by the nominal group, whose head or nucleus may be pre and/or post modified. Premodifiers define the 'thing' by means of Deictics, Numeratives, Epithets, and/or Classifiers. Pre-modification via deictics can be done through demonstratives (e.g. this, that), possessives (e.g. my, her), as well as determiners or articles (e.g. a, the, both). Numeratives pre-modify the 'thing' in terms of cardinal (one, two) or ordinal numbers (first, second), or adjectives (few, many, etc). Epithets, on the other hand, qualify the 'thing' via adjectives (e.g. glamorous, fashionable) 
whereas classifiers specify the category of the 'thing' through adjectives (e.g. Brazilian dolls) or nouns (e.g. fashion dolls) (HALLIDAY, 1994).

Postmodifiers classify the 'thing' by giving more details about it, and this is usually done through Qualifiers actualised by prepositional phrases (e.g. girls with a passion for fashion).

The Process, on the other hand, actualised by the verbal group, revolves around the concept of 'eventness', since the 'Event' in a verbal group stands for its central verb, which may or may not be preceded by other words.

Lastly, prepositional and adverbial groups surround the clause by constructing relations between the Circumstance and the Process.

The interpersonal metafunction encodes interaction and treats texts as a 'dialogue', whose most relevant interactive distinction is between the use of language (1) to exchange information and (2) to exchange goods and services. The interpersonal component involves either exchanges of information - or propositions - such as a statement or a question, or exchanges of goods and services - or proposals - such as an offer and or a command, all of which are realised by the system of Mood.

The textual component conceives language as a whole, coherent entity, whose messages are organised according to their relationship at a sentential, individual-clause level, or at a macro, overall textual-structure level. The view of clause as a message is based on the system of Theme, which "organises the clause to show what its local context is in relation to the general context of the text [...]" (MARTIN at al., 1997, p. 21). Thus, according to them, the clause is organised within a Theme and Rheme structure.

Having explained the three metafunctions proposed by Halliday (1994) and the meanings they convey, I shall restrict my analysis to the ideational metafunction and the semantic concept of transitivity as my central interest is to identify the nature of the material reality represented by the selected toy advertisements through the events, objects, participants and circumstances in which they occur (UNSWORTH, 2001). Nevertheless, although my focus is on the patterns of world experience encoded by the transitivity choices in the toy advertisements, along my analysis I do address a few features regarding the interpersonal 
interaction which constructs the relationship between the participants of that social reality.

\section{LEXICOGRAMMATICAL ANALYSIS: (1) TRANSITIVITY FEATURES}

Ten texts extracted from their corresponding Susi Collection advertisements were collected during the Christmas season of 2003, particularly because this is usually a period when most toy collections are released at the market (source: http://news.bbc.co.uk). Once collected, the data were analysed according to their lexicogrammatical features (see Appendix).

Looking at the patterns of experience in terms of the linguistic realisations encoded by the grammatical features of a text involves the identification of the choices of processes, participants and circumstances with a view to establishing how one's world is ideationally construed. Halliday's (1994) systemic functional perspective on text analysis and interpretation provides a helpful framework for such a task.

Generally speaking, transitivity structures are believed to provide a picture of reality based on the user's "model of experience" (HALLIDAY, 1994, p. 107). In other words, the investigation of the grammatical features of texts "amount to choices about how to signify (and construct) social identities, social relationships and knowledge and belief' (FAIRCLOUGH, 1992, p. 76).

In what regards the investigation of the Brazilian doll advertisements under discussion, one can notice that Susi's textual world is predominantly construed in terms of relational - $i$ s, has - and material processes - uses, wears, travels, dances and makes friends.

Out of 33 existing processes in which Susi appears as the protagonist of the actions performed in the analysed advertisements the Actor, the Senser or the Carrier-, 19 are material processes as opposed to 9 relational and 5 mental processes. Table 2 summarizes the types of verb processes and their respective number of occurrences, as found in Susi's advertisements. 


\begin{tabular}{|l|l|l|}
\hline Type of Process & Processes & $\begin{array}{l}\text { Number of } \\
\text { Occurrences }\end{array}$ \\
\hline Material & $\begin{array}{l}\text { Dresses, uses, makes new friends, brings } \\
\text { many presents, dances, puts, roots for, floats, } \\
\text { receives, watches every detail, sunbathes, loves } \\
\text { to go out, skates [V este, usa, viaja, faz, novos } \\
\text { amigos, traz, muitos presentes, dança, póe, } \\
\text { torce, flutua, recebe, não deixa escapar, } \\
\text { "pega" um sol, adora sair, patinar] }\end{array}$ & 19 \\
\hline Relational & Is, has, comes [está, é, tem, vem] & 9 \\
\hline Mental & $\begin{array}{l}\text { Loves, enjoys, lives the dream of [ama, curte, } \\
\text { vive o sonho] }\end{array}$ & 5 \\
\hline
\end{tabular}

Table 2 - Types of processes and number of occurrences in Susis ads.

Prototypically, material processes deal with concrete doings and happenings as they serve to construe the world in terms of physical experience (HALLIDAY, 1994). In the data under investigation, this occurs in terms of the activities performed by Susi, all of which compose the framework of her routine, through actions such as travelling, wearing, sunbathing, dancing and so forth. Material processes (henceforth identified as $M A p s$ ) are characterised by the inherent participation of the Actor or Agent of the action, "the one doing the material deed" (p. 103). There might also be a Goal, "a participant impacted by a doing, the one done to or with" (HALLIDAY, 1994), who can take an active or a passive role, as shown in these examples taken from my data:

\begin{tabular}{|l|l|l|l|}
\hline (Ad1) & $\begin{array}{l}\text { In the SUMMER, } \\
{[\text { Susi] }}\end{array}$ & puts on & $\begin{array}{l}\text { her bikini bottom, the pink } \\
\text { top, her sunglasses [...] }\end{array}$ \\
\cline { 2 - 4 } & No VERÃO, [Susi] & põe & $\begin{array}{l}\text { a calcinha de biquíni, o top } \\
\text { rosa, o óculos [...] }\end{array}$ \\
\cline { 2 - 4 } & Actor/Agent & MAp & Goal \\
\hline
\end{tabular}

\begin{tabular}{|l|l|l|l|l|l|l|l|}
\hline (Ad2) & SUSI & Travels & $\begin{array}{l}\text { around } \\
\text { the } \\
\text { world }\end{array}$ & makes & $\begin{array}{l}\text { new } \\
\text { friends } \\
\text { and }\end{array}$ & brings & $\begin{array}{l}\text { many } \\
\text { presents } \\
\text { to you }\end{array}$ \\
\hline
\end{tabular}




\begin{tabular}{|l|l|l|l|l|l|l|l|}
\hline & SUSI & viaja & $\begin{array}{l}\text { pelo } \\
\text { mundo }\end{array}$ & faz & $\begin{array}{l}\text { novos } \\
\text { amigos } \\
\mathrm{e}\end{array}$ & traz & $\begin{array}{l}\text { muitos } \\
\text { presentes } \\
\text { para } \\
\text { você! }\end{array}$ \\
\hline & $\begin{array}{l}\text { Actor/ } \\
\text { Agent }\end{array}$ & $M A p 1$ & Goal1 & $M A p 2$ & Goal 2 & $M A p 3$ & Goal 3 \\
\hline
\end{tabular}

\begin{tabular}{|l|l|l|l|l|}
\hline (Ad5) & $\begin{array}{l}\text { And at the } \\
\text { ball }\end{array}$ & {$[$ Susi $]$} & dances & $\begin{array}{l}\text { the whole night } \\
\text { long with BETO! }\end{array}$ \\
\cline { 2 - 5 } & E no baile & {$[$ Susi $]$} & dança & $\begin{array}{l}\text { a noite toda com } \\
\text { o BETO! }\end{array}$ \\
\cline { 2 - 5 } & & Actor $/$ Agent & $M A p$ & Goal \\
\hline
\end{tabular}

In the instances above, the choices of material processes (MAps) used in Susis advertisements help to reveal the nature of her actions by portraying rather typical upper-middle-class activities such as travelling around the world, bringing many presents, dancing, and putting on some of the items of her trendy outfit. Such grammatical choices contribute not only to create and convey a picture of Susis reality, but they also add a sense of glamour and sophistication to the representation of her universe.

Paradoxically, at the same time that such representation approximates to the child's reality through the mimetic experience by allowing him/her to assume the social roles elicited by the toy, it distances itself from their reality in that children are not yet sufficiently autonomous to partake in activities like the ones being conveyed by the doll advertisements. Since children can neither go shopping nor can they travel around the world by themselves at this specific stage of life, their contribution to the actualisation of the experience being represented in the doll advertisements becomes restricted to the imaginary, within the boundaries of their fantasy. These imaginative acts, Walton (quoted in WRIGHT, 2003) argues, provide the practice roles children "might someday assume in real life" (p. 2) as they allow them to fantasise about adulthood.

According to Halliday (1994), relational processes (Rps) relate the participant to his/her identity or description by means of two different modes, the ones of attribution and identification. This can be verified in 
a clause like Susi is beautiful and superfashion [Susi está linda e superfashion], in which the relational clause type is constructed on the basis of a Carrier + Attribute relation:

\begin{tabular}{|l|l|l|l|}
\hline (Ad3) & Susi & is & beautiful and superfashion \\
\cline { 2 - 4 } & Susi & está & linda e superfashion \\
\cline { 2 - 4 } & Carrier & $\mathrm{R} p$ & Attribute \\
\hline
\end{tabular}

Another relational clause type identified in Susi's advertisement is constructed on the basis of a Possessive relation, with the Possessor and the Possession roles located within the Identifying mode of relational processes, such as in:

\begin{tabular}{|l|l|l|l|l|}
\hline (Ad2) & Susi $[\ldots]$ & even has & an overcoat & $\begin{array}{l}\text { to travel to colder } \\
\text { places! }\end{array}$ \\
\cline { 2 - 5 } & Susi $[\ldots]$ & tem & $\begin{array}{l}\text { até um } \\
\text { sobretudo }\end{array}$ & $\begin{array}{l}\text { para viajar para os } \\
\text { lugares mais frios! }\end{array}$ \\
\cline { 2 - 5 } & Possessor & $\mathrm{R} p$ & Possession & Circumstance \\
\hline
\end{tabular}

A relational clause (either attributive or identifying) is based on the classification and categorisation of the entities involved in a process. Taking this into consideration, the importance given to the attributes beautiful, ready, superfashion, fashionable, and always fashionable [inda, pronta, superfashion, super na moda and sempre na moda] reflect the value that is granted to women's appearance in their social representation in doll advertisements. By ascribing aesthetic values to Susi, the advertiser is helping to create an ideological frame of reference in which she is supposed to fit: Susi is predominantly appraised in terms of her physical attributes. Such a gendered representation helps to unveil the ideological position of women in a society that classifies them mostly according to their looks (WRIGHT, 2003).

The social conventions established by doll advertisements are reinforced in relational clauses by means of the two meanings conveyed by two different exponents of relational processes in Portuguese, which correspond to a single one in English: to be. Whereas estar refers to a 
temporary state of being, ser relates to a permanent one. With regard to this, when one says Susi is a champion in all swimming types [Susi é campeã em todos os estilos] (Ad 8), the idea is that such an attribute constitutes an inherent quality of Susi, a constant trait of her personality. Contrarily, the clause Susi is ready to go sunbathing [Susi está pronta para "pegar um sol"] (Ad 8) evokes a sense of "presentification" to the action by highlighting Susi's current predisposition to go sunbathing.

Mental processes (MEps), on the other hand, construe a person in terms of "processes of perception, cognition and affection" (MARTIN et al, 1997, p. 105) as they deal with a participant who is involved with conscious processing (HALLIDAY, 1994), namely, the Senser. In this respect, the occurrence of mental processes such as loves, enjoys, and lives the dream of her graduation [ama, curte, and vive o sonbo de sua formatura] in Susi's advertisements seems to point to an affective representation of women's activities, which, in stark contrast with male-dominated activities, are characterized by their emotive dimension. Indeed, Susi, as a female representative of the human species, takes a passionate attitude in everything she does: Susi loves football, enjoys taking a rest in a hammock and lives the dream of her graduation party. The following occurrences from the data show Susi as the Senser who performs the mental processes constructed by the doll ads:

\begin{tabular}{|l|l|l|l|}
\hline (Ad3) & Susi & loves & Brazilian football $[\ldots]$ \\
\cline { 2 - 4 } & Susi & ama & o futebol brasileiro $[. .]$. \\
\cline { 2 - 4 } & Senser & MEp & Phenomenon \\
\hline
\end{tabular}

\begin{tabular}{|l|l|l|l|}
\hline (Ad5) & SUSI & lives & the dream of her graduation \\
\cline { 2 - 4 } & SUSI & vive & o sonho de sua formatura \\
\cline { 2 - 4 } & Senser & MEp & Phenomenon \\
\hline
\end{tabular}

\begin{tabular}{|l|l|l|l|}
\hline $\mathbf{( A d 9 )}$ & She & enjoys & a nice shade on the hammock! \\
\cline { 2 - 4 } & Ela & curte & uma gostosa sombra na rede! \\
\cline { 2 - 4 } & Senser & MEp & Phenomenon \\
\hline
\end{tabular}


The analysis of the Phenomenon - a second participant of mental clauses which can involve "any kind of entity entertained or created by consciousness" (HALLIDAY, 1994, p. 105) - in the clauses above is mostly characterised by nominal groups that point to the nature of the activities which the Senser is exposed to: resting in a hammock, enjoying football matches and living out the dream of her graduation constitute eclectic issues in the agenda of the contemporary, twentieth-century woman who knows well how to perform the juggling act that constitute hegemonic feminity: combining duties appertaining to the personal world (being a mother, a wife/girlfriend, a fashionable young woman who enjoys dating and going out) and to the public world (being (or preparing to be) a successful professional).

\section{LEXICOGRAMMATICAL ANALYSIS: (2) NOMINAL GROUPS}

Another major characteristic of the advertisements under analysis is the creation of a high degree of intimacy between the addresser of the message and the addressee. In general terms, the higher the formality of a text, the greater the social distance between the interlocutors of a given discursive event (OLIVEIRA, 2000), and viceversa.

In their investigation on the verbal and visual patterns of women's magazines, Eggins and Iedema (1997) describe the ways language choices can be used to construct solidarity between addresser and addressee. They argue that interpersonal closeness can be created, for instance, by means of direct interaction with the reader through the use of questions and of the pronoun you, whereas social distance can be marked via the use of static linguistic structures such as noun phrases and nominal groups. As they contend, a nominal group "represents reality as 'things' rather than as 'doings' [and therefore it] offers only limited ways to include reference to the reader" (p. 170).

Taking into consideration that the lexical choices in Susis advertisements reveal an interpersonal exchange with emphasis on informality and closeness, one can say that this is indicated by the use of 
(1) Epithets and Qualifiers such as superfashion, anxiously expected, superfun, cool, supertrendy, in tune, very sexy [superfashion, superesperada, superdivertidos, super na moda, supertransada, transados, antenado, gatíssima], and (2) clauses such as enjoys the sun, enjoys the beach, enjoys the shade in a hammock, sunbathe, go clubbing, is ready for an outing with her friends, skate, etc. [curte o sol numa boa, curtir uma praia, curte uma gostosa sombra na rede, pegar um sol, sair para as baladas, estar pronto para um passeio com a galera, patinar numa boa, etc.]

The role of lexis in a text is twofold: it shows and at the same time it influences - explicitly in the case of advertisements - the way one views reality. Through specific lexical choices the values and beliefs of a discourse community are unveiled, thus portraying its ideological, political and social experiences (FAIRCLOUGH, 1989; HEBERLE, 1997).

In the case of the ten advertisements under investigation, the most prominent lexical sets deal with issues related to fashion, beauty, diet, leisure, sports, career, studies and style, all of which seem to reflect the way women are portrayed and expected to behave in society (JOHNSON; GANNON, 1997). They are filled with what Riddick (2002) refers to as "positive reflections of society and femininity" (p.2) in which the goals achieved by the dolls are nothing but the "socially accepted ones" (p.2). They also help to convey some aesthetic expectations of women by reinforcing the unattainable standards of feminine beauty by means of the creation of an ideal miniaturised female representation, one that is at the same time "thin, tall, long-legged, young, vibrant, sexy, and beautiful” (WRIGHT, 2003, p. 5).

Table 3 summarises the occurrences of nominal groups and epithets related to fashion and beauty in Susi's ads 1, 2, 3, 4, 7 and 9. As can be seen in this table, the high incidence of lexical items related to fashion and beauty present in the selected advertisements points to the role they establish for women in society, the contexts where women are placed, as well as the ideological - and idealized - constructions of womanhood made explicit in the discourse of advertising. It also naturalises contemporary practices of consumption associated to certain standards of living by making reference to a woman who is expected to be permanently pretty through the use of attitudinal Epithets and Qualifiers such as 'always beautiful' ['sempre linda'] (Ads 1,3 and 9; 4 occurences); 'very sexy' ['gatíssima'] (Ad 4, 1 occurence), always endowed with all her charms 


\section{8}

('with lots of charme' ['com muito charme'], Ad 1; 'with all her charme' ['com todo charme'], Ad 2; 2 occurences), highly elegant and with a strong sense of fashion ('superelegant' ['superelegante]', Ad 2; 'superfashion' ['superfashion'], Ad 3; 'superstylish" ['superprodurida'], Ad 4; 'very fashionable' ['super na moda'], Ad 9; 'a very trendy look' ['no maior visual da moda'], Ad 7; 'cool and different looks' ['visuais transados e diferentes'], Ad 1; 'all ready' ['prontinha'], Ad 3; and 'ready' ['pronta'], Ad 9; 1 occurrence each).

\begin{tabular}{|c|c|c|c|c|c|}
\hline \multicolumn{6}{|c|}{ Fashion/Beauty } \\
\hline Ad 1 & $\mathrm{Ad} 2$ & Ad3 & Ad 4 & Ad7 & Ad 9 \\
\hline $\begin{array}{l}\text { with lots of } \\
\text { versatility } \\
\text { cool and } \\
\text { different } \\
\text { looks } \\
\text { always } \\
\text { beautiful the } \\
\text { whole year } \\
\text { long } \\
\text { with lots of } \\
\text { charme and } \\
\text { good taste } \\
\text { dress with a } \\
\text { flowered } \\
\text { skirt } \\
\text { pink top } \\
\text { clogs } \\
\text { upper part } \\
\text { in net with } \\
\text { long sleeves } \\
\text { tennis }\end{array}$ & $\begin{array}{l}\text { With all the } \\
\text { charme of a } \\
\text { superelegant } \\
\text { VARIG flight } \\
\text { attendant }\end{array}$ & $\begin{array}{l}\text { inspired on } \\
\text { Milene's } \\
\text { uniform } \\
\text { beautiful and } \\
\text { superfashion } \\
\text { all ready } \\
\text { the gift of a } \\
\text { hair strap }\end{array}$ & $\begin{array}{l}\text { well-dressed } \\
\text { very sexy } \\
\text { five colored } \\
\text { and bright } \\
\text { hair clips } \\
\text { two hair } \\
\text { pieces }\end{array}$ & $\begin{array}{l}\text { three } \\
\text { different } \\
\text { very } \\
\text { fashionable } \\
\text { outfits } \\
\text { hair clips }\end{array}$ & $\begin{array}{l}\text { beautiful (2 } \\
\text { occ) } \\
\text { very } \\
\text { fashionable } \\
\text { with lots of } \\
\text { very cool } \\
\text { accessories } \\
(2 \text { occ) } \\
\text { without the } \\
\text { skirt } \\
\text { with the } \\
\text { bikini, } \\
\text { sunglasses } \\
\text { and the bag } \\
\text { all ready }\end{array}$ \\
\hline
\end{tabular}

Table 3 - Epithets and nominal groups in Susis ads related to fashion and beauty. ${ }^{1}$

\footnotetext{
${ }^{1}$ Portuguese version: ad 1) com muita versatilidade - visuais transados e diferentes - sempre linda, o ano todo - com muito charme e bom gosto - vestido com saia florida - top rosa - tamanco parte superior em tela com mangas compridas - tennis; ad 2) com todo o charme de uma aeromoça VARIG - superelegante; ad 3) inspirada no uniforme da Milene - linda e superfashion - prontinha - faixa de cabelo de presente; ad 4) superproduzida - gatíssima - cinco enfeites de cabelo coloridos e brilhantes - dois apliques; ad 7) três conjuntos diferentes no maior visual da moda - enfeites de cabelo; ad 9) linda (2 occ) - super na moda com um montão de acessórios ultralegais $(2$ occ $)$ - sem a saia com o biquíni, óculos e bolsa pronta.
}

ALMEIDA - Beyond the playground... 
The Brazilian doll Susi is also evaluated in relation to the clothes she wears, all of which contribute to create her versatile and trendy look:

$[\ldots]$ the top is double-faced and the pieces of clothing [...] cool and different looks! [o top é dupla-face $e$ as peças de roupa [...] visuais transados e diferentes!] (Ad1)

$[\ldots]$ the dress with a flowered skirt and over it the pink top $[0$ vestido com saia florida e sobre ele, o top rosa] (Ad1)

$[\ldots]$ the bikini bottom, the pink top, the glasses [a calcinha de biquíni, o top rosa, o [sic] óculos] (Ad1)

[...] the dress, the blue top and, underneat it, the foldedhemmed trousers [o vestido o top azul e por baixo, a calça com barras dobradas] (Ad1)

[...] blue top, trousers, coat and long-legged boots [top azul, calça comprida, casaco e botas de cano alto] (Ad1)

Dress with a flowered skirt and upper part in fabric with long sleeves, pink top and clogs Vestido com saia florida e parte superior em tela com mangas compridas, top rosa $e$ tamanco] (Ad1)

Dress with a flowered skirt and upper part in flowered fabric with long sleeves, blue top, folded-hemmed trousers and tennis shoes Vestido com saia florida e parte superior em tela florida com mangas compridas, top azul, calça com barras dobradas e tennis] (Ad1)

[...] a white shirt under a coat and she even has an overcoat [...] $[[\ldots .$.$] camisa branca por baixo do blazer e tem até um sobretudo$ $[\ldots]](\operatorname{Ad} 2)$

$[\ldots]$ Five colorful and shiny hair clips $[\ldots][[\ldots]$ cinco enfeites de cabelo coloridos e brilhantes [...]] (Ad4)

Without the skirt and with the bikini, glasses and bag $[\ldots]$ [Sem a saia e com o biquíni, óculos e bolsa [...]] (Ad9)

$[\ldots]$ with lots of very cool accessories! $[[\ldots]$ com um montão de acessórios ultralegais!] (Ad9)

By focusing on items such as her flowered skirt ('saia florida', Ad 1; 3 occurences), pink and blue tops (Ad 1; 4 occurences), dress ('vestido' Ad 
1; 4 occurences), bikini bottom (Ads 1 and 9; 2 occurrences), bag ('bolsa', Ads 7 and 9; 3 occurences); colorful and bright hair clips ('enfeites de cabelo coloridos e brilhantes', Ad 4); supercool accessories ('acessórios ultralegais', Ad 9; 2 occurences), Susi's text could be inserted in what Caldas-Coulthard and van Leeuwen (2002) have named a "catwalk genre", whereby the "models are described and adults [become] interested in the attributes and features of the doll" (p. 106).

Indeed, the Epithets, Classifiers and Qualifiers employed in the nominal groups identified in Susis advertisements contribute to positively evaluating Susi in the advertising discourse about her. Placed in rather specific contexts within the public or the private sphere, Susi plays roles which vary from that of a flight hostess to that of an undergraduate student out at her graduation party, from that of Beto's girlfriend to that of a football player or supporter, and whenever she assumes the position of a sportswoman, suchas as a swimmer or a roller-skater, she is placed in hot, sunny environments. Her social practice (FAIRCLOUGH, 1995a, 1995b, 1992, 1989) is thus constituted by a compromise between the public and the domestic sphere, in both of which she is expected to match the demands of a society that sees in the juggling of work, home and leisure activities the true function of women's lives (MORIN; ROSENFELD, 1998).

This is also revealed in the lexical items found in Susis advertisements in which concern about diets, body image and professional career help to compose the image of a multi-skilled woman whose responsibility is foregrounded by the evaluative lexis in the advertisements. To illustrate these complementary, albeit paradoxical, roles attributed to women, Table 4 includes other prevalent lexical sets found in the doll advertisements together with their number of occurrences.

The focus on lexical items related to Studies and Career, through positive Qualifiers in nominal groups such as the dream of her graduation, a very special date, anxiously expected from everyone, one of the happiest days of your life [sonho de sua formatura, data muito especial, superesperada por todos, um dos dias mais felizes de sua vida] (Ad 5), help to support the view that the overrepresented "practices of domesticity" (CALDAS-COULTHARD; VAN LEEUWEN, 2002, p. 97) - which include placing the doll in the context of a house taking care of a baby or preparing the food - are no longer 
the only potential social meanings conveyed in toy advertisements. The emphasis given to women's professional roles in doll advertisements like Susis calls attention to the gradual change of social position experienced by women over the last decades.

\begin{tabular}{|c|c|c|c|}
\hline Diet & Leisure & Studies/Career & Sports \\
\hline Ad 4 & Ads 4 and 9 & Ad 5 & Ads 8 and 10 \\
\hline $\begin{array}{l}\text { thirst } \\
\text { juice }\end{array}$ & $\begin{array}{l}\text { nights out (2 } \\
\text { occ) } \\
\text { beach }\end{array}$ & $\begin{array}{l}\text { dream of her graduation } \\
\text { a very special date, anxiously } \\
\text { expected by everyone } \\
\text { photos } \\
\text { graduation cerimony } \\
\text { the whole class wearing graduation } \\
\text { robes } \\
\text { mortar board on the head } \\
\text { ball ( } 2 \text { occ) } \\
\text { one of the happiest days of your } \\
\text { life } \\
\text { diploma } \\
\text { graduation robe and mortar board } \\
\text { graduation ring } \\
\text { invitation cards } \\
\text { photo albums }\end{array}$ & $\begin{array}{l}\text { crawl, backstroke } \\
\text { swimming, butterfly } \\
\text { swimming } \\
\text { champion } \\
\text { superfun acessories } \\
\text { backpack } \\
\text { swimming cap } \\
\text { towel } \\
\text { board } \\
\text { buoys } \\
\text { note pad } \\
\text { completely safe } \\
\text { helmet } \\
\text { knee protectors } \\
\text { elbow protectors } \\
\text { skates } \\
\text { small bag } \\
\text { water bottle }\end{array}$ \\
\hline
\end{tabular}

Table 4 - Epithets and nominal groups in Susi's ads related to diet, leisure, studies, career and sports. ${ }^{2}$

By no means do these lexical choices suggest the elimination or the substitution of old domestic roles for new ones; rather, they convey the multiplicity and eclecticism of the activities which compose the agenda of the contemporary woman. This includes women's [1] participation in a range of activities such as going shopping, going to

\footnotetext{
2 Portuguese version: ad 4) sede - suco; ads 4 and 9) baladas (2 occ) - praia; ad 5) sonho de sua formatura - data muito especial, superesperada por todos - fotos - sessão solene de entrega dos diplomas - turma toda vestindo beca - capelo na cabeça - baile (2 occ) - um dos dias mais felizes de sua vida - diploma - beca e capelo - anel de formatura - convites - álbum de fotos; ads $\mathbf{8}$ and 10) nado livre, de costa, borboleta - campeã - acessórios superdivertidos - mochila - touca toalha - prancha - bóias - prancheta de anotações - com toda a segurança - capacete - joelheiras - cotoveleiras - patins - bolsinha - garrafinha de água.
} 
work, playing sports ('the charme of a flight attendant' ['charme de uma aeromosa'], Ad 2; 'crawl' ['nado livre'], Ad 8) and women's [2] achievement, such as following a career and being successful ('graduation cerimony' ['sessão solene de entrega dos diplomas', 'graduation ring' ['anel de formatura', Ad 5).

Another role which contemporary women are ideally expected to accomplish is related to their role as companion to the men in their lives, and other love-related issues. For this reason, the presence of Beto in Susi's universe deserves some further attention. Lexical items found in Susi's advertisements have revealed that, like Susi, her boyfriend Beto is deeply concerned with fashion, and his style is taken as modern and casual as can be exemplified by the following lexical choices present in Beto's advertisements: 'a casual and fashionable style' ['estilo fashion e descontraido'] (a nominal group with two Qualifiers, fashionable and casual); and Qualifiers such as 'always in tune with the new trends from the fashion world' ['sempre "antenado" com as novidades do mundo da moda'] (Ad 6).

All in all, what these examples from the analysis and discussion on the lexical choices of Susis advertisements seem to reveal is the portrayal of Susi's universe in a highly evaluative manner, given that they point to a world mainly construed in terms of aesthetic values through words and nominal groups like superfashion, superfashion look. [maior visual da moda], superstylish [superprodurida], always beautiful [sempre linda] and very sexy [gatíssima], all of which are target to reinforcing the construction of an idealized discourse of contemporary womanhood through the semiotic representation of women's lives as encompassing a professional career, leisure activities and the pursuit of female beauty.

\section{FINAL REMARKS}

The discussion on the lexico-grammatical features of the advertisements of Brazilian doll Susi has helped to shed some light on how the image of Brazilian young women is conveyed by the discourse of two-dimensional vehicles such as fashion dolls' advertisements.

In this sense, the analysis of Susi's texts has corroborated the hypothesis that Brazilian women are generally portrayed as being more passive than men, as receivers of the attributes assigned to them mainly 
on the basis of their aesthetic qualities, via nominal groups which essentially focus on items such as fashion, beauty and diet. However, an attempt has been made to revamp this submissive image through the depiction of Susi as involved in professional and leisure activities, through lexical sets which emphasise items such as sports, leisure, studies and career, as well as through the nature of the material processes which construct Susis world in terms of physical experience (wearing, travelling, dancing, sunbathing, roller-skating, etc).

Be that as it may, while discussing the construction of gender in the representation of toys, Caldas-Coulthard and van Leeuwen (2001) have contended that "some toys are designed for action, others for posing" (p. 98), and dolls like Barbie - one of their objects of investigation - and Susi are included in this group of toys.

The fact that dolls like Barbie and Susi can neither stand by themselves, hold anything in their hands, open their legs wide apart nor move their head in any direction (CALDAS-COULTHARD; VAN LEEUWEN, 2001) certainly conveys gendered meanings related to the way women are semiotically represented through girls' dolls. In stark contrast to women's 'submissive' representation, boys' dolls - except for Susi's Beto - are endowed with a movement potential which allows them to stand by themselves without falling over, hold objects, move their head sideways and open their legs wide apart (CALDAS-COULTHARD; VAN LEEUWEN, 2001). The kinetic differences encoded by the visual representations of toys for boys and girls help to capture the essence of the social view of men's and women's roles in contemporary society.

\section{REFERENCES}

BUTT et al. Using functional grammar: an explorer's guide. Sydney: Macquarie University, 1998.

CALDAS-COULTHARD, C. R.; LEEUWEN, T. V. Baby's first toys and the discursive constructions of babyhood. Folia linguistica, v. 35, n. 1-2, 2001.

$\overline{\text { gendered social actors. In: LITOSSELITI, L.; SUNDERLAND, J. (Eds.). }}$ 
Gender identity and discourse analysis. Amsterdam: John Benjamins, 2002. p. $91-108$.

DOWNIE, A. Brazilian girls turn to a girl more like them. In: Women making history today. $20^{\text {th }}$ January 2000 . Viewed on $12^{\text {th }}$ September 2005, http://www.csmonitor.com/atcsmonitor/specials/women/mirror/mirror0120 00.html.

EGGINS, S.E.; IEDEMA, R. Difference without diversity: the semantics of women's magazines. In: WODAK, R. (Ed.). Gender $\&$ discourse. Thousand Oaks, Calif: Sage: 1997. p. 165-196.

FAIRCLOUGH, N. Language and power. London: Longman, 1989.

. Discourse and social change. Cambridge: Polity Press, 1992.

$1995 a$.

Critical Discourse analysis: the critical study of language. London: Longman,

Media discourse. New York: Edward Arnold, 1995b.

HALLIDAY, M.A.K. An introduction to functional grammar. London, Edward Arnold, 1994.

HEBERLE, V. An investigation of textual and contextual parameters in editorials of women's magazines. Unpublished Doctoral dissertation. Florianópolis: Universidade Federal de Santa Catarina, 1997.

JOHNSON, E.; GANNON, J. The rape of our youth - a sociological analysis of children's television advertising. Available on http://itstlawu.edu/ advertiz/children, 1997.

MARTIN, J. R.; MATTHIESSEN, C.. M. I. M.; PAINTER, C. Working with functional grammar. London: Arnold, 1997.

MORIN, R.; ROSENFELD, M. With more equity, more sweat. The Washington Post. Washington, 22 ${ }^{\text {nd }}$ March, p. A1, 1998.

OLIVEIRA, M. Exploring social identities and youth social change in ethnic minority music. Unpublished Dissertation Proposal Statement. Florianópolis: Universidade Federal de Santa Catarina, 2000.

PEERS, J. The fashion doll: from Bébé Jumeau to Barbie. Oxford: Berg, 2004. RIDDICK, K. Barbie: the image of us all. Paper linked to the Florida Atlantic University homepage [website on-line] (Boca Raton, FL., 2001 [cited 1 June 2002]); available from http://www.fau.edu/library/barblink.htm, 2002. 
UNSWORTH, L. Describing visual literacies. In: Teaching multiliteracies across the curriculum - changing contexts of texts and image in classroom practice. Philadelphia: Open University Press, 2001. p. 71-112.

WRIGHT, L. The wonder of Barbie: popular culture and the making of female identity. Essays in Philosophy, v. 4, n.1, 2003.

\section{APPENDIX: Susi's advertisements (extracted and adapted from www. estrela.com.br)}

\section{Ad1 - Susi Quatro Estações}

Primavera, verão, outono, inverno....

Não importa a estação, SUSI está sempre na moda. E com muita versatilidade: o top é dupla-face e as peças de roupa podem ser combinadas para criar visuais transados e diferentes! Na PRIMAVERA, SUSI usa o vestido com saia florida e sobre ele, o top rosa. No VERÃO, põe a calcinha de biquíni, o top rosa, o [sic] óculos e curte o sol numa boa. Quando chega o OUTONO, ela usa sobre o vestido o top azul e por baixo, a calça com barras dobradas. E.... BRRRRR! Nos dias frios de INVERNO, SUSI veste top azul, calça comprida, casaco e botas de cano alto. Sempre linda, o ano todo, com muito charme e bom gosto!

SUSI não pára em pé sozinha.

DETALHE Primavera!!!! Vestido com saia florida e parte superior em tela com mangas compridas, top rosa e tamanco!

DETALHE Outono!!!! Vestido com saia florida e parte superior em tela florida com mangas compridas, top azul, calça com barras dobradas e tênis!

DETALHE Você ganha um lindo porta-lápis para montar!

\section{Ad 2 - Susi Aeromoça}

Com todo o charme de uma aeromoça VARIG, SUSI viaja pelo mundo, faz novos amigos e traz muitos presentes para você!

SUSI não pára em pé sozinha.

DETALHE Superelegante, SUSI veste camisa branca por baixo do blazer e tem até um sobretudo para viajar para lugares mais frios!

DETALHE Sua mala tem rodinhas, abre e fecha de verdade e a altura da alça pode ser ajustada!

DETALHE Para completar a brincadeira, você ganha um mundo de presentes: passaporte, revista do Variguinho, "bottom", jogo da memória e adesivos para enfeitar a mala! 


\section{Ad 3 - Susi Seleção By Milene Domingues}

Susi ama o futebol brasileiro e é fã de Milene Domingues. E nada melhor do que torcer pelo Brasil vestindo as cores da seleção. Inspirada no uniforme da Milene, Susi está linda e superfashion, prontinha para torcer como nunca. Vai lá, Brasil!

Susi não pára em pé sozinha.

DETALHE SHOW DE BOLA! Uma faixa de cabelo de presente pra você usar!

\section{Ad 4 - Susi Piscina e Diversão}

SUSI e BETO não páram em pé sozinhos.

Deu sede? Que tal um "suco"?... HUUM!

SUSI adora sair para baladas. Superproduzida e gatíssima, ela não deixa escapar nenhum detalhe!

DETALHE Para você acompanhar SUSI nas baladas, ganha cinco enfeites de cabelo coloridos e brilhantes e mais dois apliques!

\section{Ad 5 - Susi Baile de Formatura}

SUSI vive o sonho de sua formatura. Uma data muito especial, superesperada por todos! As fotos com os colegas, a sessão solene de entrega dos diplomas com a turma toda vestindo beca e com o capelo na cabeça, o baile - dançando a noite toda com Beto.... Puxa, este é um dos dias mais felizes de sua vida!

SUSI não pára em pé sozinha e não segura o canudo como nas fotos.

DETALHE Para receber o diploma, SUSI usa beca e capelo!

DETALHE E no baile, dança a noite toda com o BETO!

DETALHE Um lindo "anel de formatura" para você!

DETALHE Tem diploma, convites e "álbum de fotos"!

\section{Ad 6 - Beto Estilo}

Com seu estilo fashion e descontraído, Beto está sempre "antenado" com as novidades do mundo da moda, pronto para um passeio com a galera! Beto não pára em pé sozinho.

\section{Ad 7 - Cartela Susi Visual da Moda}

São três conjuntos diferentes para você deixar sua SUSI no maior visual da moda. E as cartelas têm a forma de uma bolsa!

Sapatos e enfeites de cabelo não incluídos. 


\section{Ad 8 - Susi Aula de Natação}

Nado de costas, borboleta ou nado livre? SUSI é campeã em todos os estilos!

Ela flutua de verdade e vem com um montão de acessórios superdivertidos!

Marcador de raias não incluído.

DETALHE Tem mochila, touca, toalha!

DETALHE Tem prancha e bóias!

DETALHE E até "prancheta de anotações"!

\section{Ad 9 - Susi Moda Praia}

SUSI está linda e super na moda para curtir uma praia. E com um montão de acessórios ultralegais!

QUE SOSSEGO! Ela curte uma gostosa sombra na rede!

DETALHE QUE DEMAIS!

A bolsa vira toalha!

DETALHE Um montão de acessórios superlegais!

DETALHE QUE LINDA!

Sem a saia e com o biquíni, óculos e bolsa, Susi está pronta para "pegar um sol"!

\section{Ad 10 - Susi Patinadora}

SUSI adora patinar!

Mas com toda a segurança e sempre linda, com uma roupa supertransada, leve e confortável!

DETALHE Capacete, joelheiras e cotoveleiras para patinar numa boa!

DETALHE Os patins têm rodinhas que giram de verdade!

DETALHE A bolsinha e a "garrafinha de água" vão presas na cintura!

Recebido em 12/01/08. Aprovado em 09/07/08.

Título: Para além da hora do recreio: a representação da realidade em anúncios de bonecas de moda

Autor: Danielle Barbosa Lins de Almeida

Resumo: Este artigo analisa os significados expressos pelo discurso dos anúncios virtuais da boneca brasileira Susi, extraídos do site www.estrela.com.br. Apoiado na Gramática Sistêmico-Funcional de Halliday (1994), o artigo analisa as estruturas de transitividade e os grupos nominais, ao enfocar os temas que os anúncios da Susi contemplam, os papéis que eles refletem e o tipo de relacionamento que é estabelecido entre seus participantes. A análise das estruturas de transitividade dos anúncios da Susi aponta para a construção de um mundo textualmente caracterizado por atividades típicas de classe média-alta, que giram em torno de processos materiais e relacionais. As análises dos itens lexicais especificam a natureza destas atividades, ao abordarem temas 
como moda, beleza, dieta, esportes, lazer, estudos e carreira, alterando, assim, uma visão tradicional da figura feminina, exclusivamente centrada no contexto doméstico.

Palavras-chave: discurso; anúncio publicitário; gênero social; brinquedo; gramática sistêmico-funcional.

Titre: Au-delà de l'horaire de la récréation: la représentation de la réalité dans des annonces publicitaires concernant des poupées de mode

Auteur: Danielle Barbosa Lins de Almeida

Résumé: Cet article fait l'analyse des sens exprimés par les discours virtuels de la poupée brésilienne Susi, extraits du site www.estrela.com.br. Appuyé dans la Grammaire Systémique Fonctionnel de Halliday (1994), l'article analyse les structures de transitivité et les groupes nominaux, en focalisant les sujets que les annonces publicitaires de la Susi contemplent, les rôles qu'ils postulent et le type de rapport qui est établi parmi les participants. L'analyse des structures de transitivité des annonces publicitaires de la Susi indiquent la construction d'un monde textuellement caractérisé par des activités typiques de la classe moyenne/haute, qui tourne autour de procès matériels et relationnels. Les analyses des thèmes lexicaux spécifient la nature de ces activités, tout en s'adressant aux sujets comme mode, diète, sports, loisirs, études et carrière, changeant, ainsi, une vision traditionnelle de la figure féminine, exclusivement centrée dans le contexte familial.

Mots-clés: discours; annonce publicitaire; genre social; jouet; grammaire systémique fonctionnel.

Título: Para más allá de la hora del recreo: la representación de la realidad en anuncios de muñecas de moda

Autor: Danielle Barbosa Lins de Almeida

Resumen: Este artículo analiza los significados expresados por el discurso de los anuncios virtuales de la muñeca brasilera Susi, extraídos del sitio www.estrela.com.br. Apoyado en la Gramática Sistémico-Funcional de Halliday (1994), el artículo analiza las estructuras de transitividad y los grupos nominales, al enfocar los temas que los anuncios de Susi contemplan, los papeles que ellos reflejan y el tipo de relación que es establecido entre sus participantes. El análisis de las estructuras de transitividad de los anuncios de Susi apunta para la construcción de un mundo textualmente caracterizado por actividades típicas de clase media-alta, que giran en torno de procesos materiales y relacionales. Los análisis de los ítems lexicales especifican la naturaleza de estas actividades, al abordar temas como moda, belleza, dieta, deportes, ocio, estudios y carrera, cambiando, de esta manera, una visión tradicional de la figura femenina, exclusivamente centrada en el contexto doméstico.

Palabras-clave: discurso; anuncio publicitario; género social; juguete; gramática sistémico-funcional. 